\title{
新設された片側式アーケード内 FIELD INVESTIGATION ON AIR 部の気温分布性状 TEMPERATURE DISTRIBUTION INSIDE A NEWLY-BUILT SEMI-CLOSED ARCADE
}

\section{辻原万規彦 $-* 1$ \\ 田中 稔— $* 3$ \\ キーワード : \\ アーケード，現場実測，気温，垂直分布，日射，換気}

Keywords :

Arcade, Field measurement, Air temperature, Vertical distribution, Solar radiation, Ventilation

\author{
Makihiko TSUJIHARA - * 1 \\ Minoru TANAKA — $* 3$
}

Thermal environment, especially air temperature distribution, inside the semiclosed arcade located at Nagasaki was investigated on field observations both in summer 2000 and in winter 2001. Air temperature at the height of 1.0 meter in the occupied zone was a little higher than outside air temperature both in summer and in winter. In the daytime of summer, vertical distribution of air temperature showed a slope of high temperature in the upper part and low temperature in the lower part. However, both in the nighttime of summer and winter, vertical distribution of air temperature did not show a slope.

\section{1.はじめに}

日本各地の中心市街地には，アーケードをもつ商店街が数多く存 在する1）が，アトリウムなどとは異なり，その内部の温熱環境につ いてはこれまでほとんど研究がなされておらず，熱睘境設計を考慮 した整備が十分にはできていないのが現状である。

しかしながらアーケードをはじめとする都市の「半戸外空間」 注 1)は, アトリウムなどと異なり, 空調機器などの機械的な環境調 整手法を用いないため，「環境への負荷が少なく，快適な都市空間 を提供できる」可能性を持ち, 今後の活用が大いに期待される。

このような背景のもとで，筆者らはこれまでに，温暖多照地域に おける全蓋式アーケード注 2) 内部の気温分布性状 ${ }^{2)}$ と温熱環境の評 価 ${ }^{3)}$ に関する研究をはじめとして, 都市の「半戸外空間」に関する 研究出を行ってきた。

本研究では，これらの研究に続けて，新設された片側式アーケー ド内部の温熱環境について，1）アーケード内部の気温分布性状の 把握，2）アーケード内部の温熱環境における快適性の評価，の2 つの視点から, 夏季と冬季の 2 度に渡って, その実態を明らかにし, アーケード内部の温熱環境に関する基礎資料を整備することを目的 としている。同時に，全盖式アーケード内部の温熱環境と比較する ことによって，両者の特質を明確にし，今後の整備方針を示そうと するものである。本稿では，このうち 1）について報告し，2）に ついては稿を改める予定である。

なお本稿の一部は，文献5）および6）で発表した内容に修正・加 筆を行ったものである。

\section{2. 測定対象アーケードの概要}

測定対象とした片側式アーケードをもつ長崎浜市電車通商店街は, 長崎県長崎市の中心部, 中央橋交差点からほほ南東方向に延びる道 路延長 $360.11 \mathrm{~m}$, 歩道幅員 $4 \mathrm{~m}$ の商店街である（図 1）。測定対象 アーケードは, 1969年11月に建設された ${ }^{7)}$ 後, 部分的な改修を行っ てきたものの老朽化が激しかった既存のアーケードを取り外し， 2000年 3 月に新設されたものである。

アーケードの構造は，躯体が鉄骨造平屋建，基礎が鋼製杭基礎で あり, 幅員 $4 \mathrm{~m}$, 天井高さ $6.55 \mathrm{~m}$, 屋根高さ $7.85 \mathrm{~m}$ である。また屋 根（図 2）には，厚さ $12 \mathrm{~mm}$ の熱線吸収ガラスと厚さ $8 \mathrm{~mm} の$ 透明板カ ラスによる複層ガラス，日除け（図 2 ）には飛散防止フィルム張の 厚さ $12 \mathrm{~mm}$ の熱線吸収ガラスが用いられている。

また，「長崎の気候区分は，太平洋側九州型に属し，その特色は 「温暖多雨」といえる。温暖になる原因としては，暖流である対馬 海流が近海をながれていることと，長崎自体が海に面しているので 海洋性をしめすためである。多雨期は 6 月〜 7 月の梅雨期，8月〜 9 月の台風期となっている。」 ${ }^{8)}$

\section{3. 測定の概要}

\section{1 測定日時}

夏季の測定は，2000年 8 月 21 日（月）夕方から 8 月25日（金） 早朝まで行った。また冬季の測定は，2001年 1 月16日（火）夕方 から1月19日（金）早朝まで行った。

\footnotetext{
*1 熊本県立大学環境共生学部 講師・博士 (工学)

( 于862-8502 熊本市月出 3 丁目1-100)

*2 熊本県立大学環境共生学部 助手・修士(工学)

*3 神村鉄工侏）専務取締役
}

*1 Senior Lecturer, Faculty of Environmental and Symbiotic Sciences, Prefectural University of Kumamoto, Dr. Eng.

*2 Assistant, Faculty of Environmental and Symbiotic Sciences, Prefectural University of Kumamoto, M. Eng.

*3 Executive Director, Kamimura Iron Works Co. Ltd. 


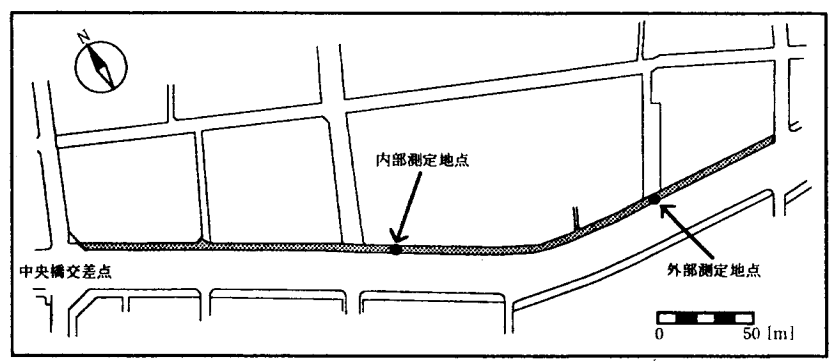

図 1 測定対象アーケードと測定地点

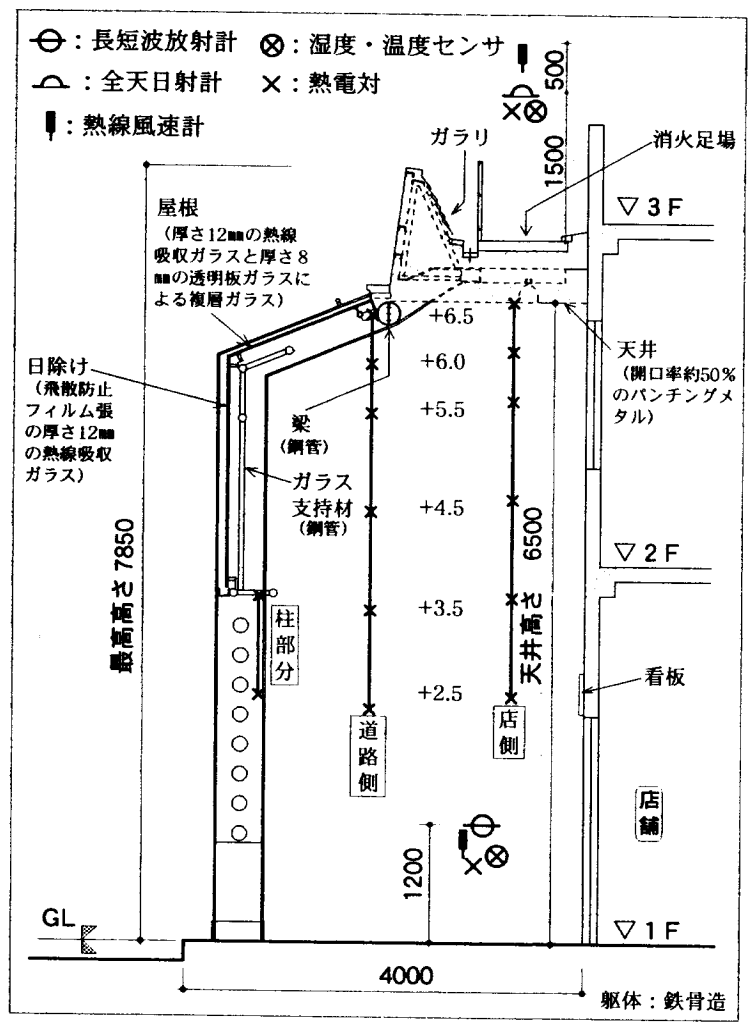

図 2 測定対象アーケード断面図

\section{2 測定方法}

内部測定地点は, 通行人の妨げにならず，かつアーケード内部を 代表すると考えられる場所を選定し（図 1 ），その上方のアーケー ド内部の気温分布を測定した（図 2)。

比較のための外部測定地点は，できるだけ周囲が開けている場所 として, 道路との交差部分の上にアーケードが架けられている地点 の上方，屋上を選定した（図 1 ）。外気温測定の際に，センサを日 射計の取付台の下に位置させることにより，日射の遮蔽を図った。 なお本稿では, アーケード内部で測定した空気の温度を「気温」, アーケードの外部・屋上で測定した空気の温度を「外気温」と記す。 各地点での測定項目と使用した測定機器などについて表 1に示す。 これらのデータは 1 分間隔で測定を行い, データロガーに記録させ た。なお内部の温熱環境に関する自動測定は, 夏季では 8 月 21 日が 22:00まで, 22から24日が5:00から23:00まで行い，また冬季では 1 月16日が23:00まで，17日と18日が4:45から23:00まで行った。

また別に内部測定地点では, 手動測定により, 乾球温度, 湿球温 度ならびに風速を，9:00から21:00の間，2時間おきに測定した。
同時に代表的な表面温度合計22点を赤外線表面温度計で測定した。

アーケード内部の気温のうち, 地上 $1 \mathrm{~m} の$ 気温測定の際には，日 射の遮蔽を図るためにセンサを銀紙で覆われた小型の夎の下に位置 させた。それ以外の気温は, 日射の影響を受けるため, 中村らの式 9)に従って補正した。

\section{表 1 测定項目と使用測定機器}

\begin{tabular}{|c|c|c|}
\hline 自副 & 测定項目 & 測定機器など \\
\hline \multirow{4}{*}{$\begin{array}{l}\text { 気 } \\
\text { 温 } \\
\text { 分 } \\
\text { 布 }\end{array}$} & 気温（店価） & T型樰細熱電対 線径 $0.08 \mathrm{nnm}$ （6 点） \\
\hline & 気温（道路側） & T型極細熱電対 線径 $0.08 \mathrm{~mm}$ （6点） \\
\hline & 気温（柱部分） & 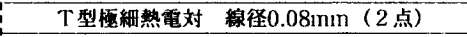 \\
\hline & データロガー* & THERMODAC EF（江藤電気） \\
\hline \multirow{6}{*}{$\begin{array}{c}\text { 内 } \\
\text { 部 } \\
\dot{0} \\
\text { 地 } \\
\text { 上 }\end{array}$} & 風速 & 熱線風速計 V-01-AND2N（アイ電子技研） \\
\hline & 湿度・温度 & 湿度・温度センサ $2119 \mathrm{~A}$ (江藤電気) \\
\hline & 気温 & T型签紐熱電対 線经 $0.08 \mathrm{~mm}$ \\
\hline & 日射・長波故射 & 長短波故射計 MR-40（英弘精機） \\
\hline & 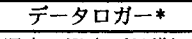 & THERMODAC EF（江藤電気） \\
\hline & 湿度・温度（予備） & 小型温鼬度記録装置 TR-72（ティアンドデイ） \\
\hline \multirow{6}{*}{$\begin{array}{l}\text { 外 } \\
\text { 部 } \\
\dot{2} \\
\text { 屋 } \\
\text { 上 }\end{array}$} & 風速 & 熱線禹速計Ｖ-01-AND2N（アイ電子技研） \\
\hline & 湿度 - 温度 & 湿度・温度センサ 2119A（江藤電気） \\
\hline & 外気温 & T型极細熱電対 線径 $0.08 \mathrm{~mm}$ \\
\hline & 日射 & 全天日射計 MS-601 (英弘精機) \\
\hline & データロガー* & THERMODAC EF（江藤電気） \\
\hline & 湿度・温度（予備） & 小型温湿度記録装置 TR-72（ティアンドデイ） \\
\hline 手为 & & 測定機器など \\
\hline \multirow{3}{*}{$\begin{array}{l}\text { 内 } \\
\text { 部 }\end{array}$} & 通風乾湿計 & アスマン通風乾湿計 SK-RHG（佳藤計量器） \\
\hline & 風速計 & 定温型熟式風速計 6071 （日本科学工業） \\
\hline & 赤外線表面温度計 & 放射温度ハイテスタ 3444 (日置電機) \\
\hline
\end{tabular}

\section{3 測定期間中の気象状況}

8月中〜下旬の長崎県の天気概況は，以下の通りであった ${ }^{10 ） 。 ~}$ 8月中旬は, 前半は太平洋高気圧に覆われ, 概ね晴の天気となっ たが, 後半は気圧の谷の通過や太平洋高気圧の周辺部となった影響 で，まとまった雨となった。 8 月下旬は，太平洋高気圧が強まり晴 れて暑い日が多く，長䗁市では28日にこの夏の最高気温 $35.6^{\circ} \mathrm{Cを}$ 記 録した。なお，夏季の測定期間前後の日別天気概況を表 2に示す（網 掛け部分は，測定期間中であることを示す。冬季も同様。）11）。

1 月上〜中旬の長崎県の天気概況は, 以下の通りであった ${ }^{12)} 。$

1 月上旬は, 前半は冬型の気圧配置, 後半は低気圧や前線の影響 を受け, 気温は前半は平年より低く, 後半は平年より高く推移した。 1 月中旬は, 前線, 低気圧ならびに冬型の気圧配置の強まりの影響 で, 量や雨または雪の日が多く, 気温は平年を下回った。冬型の気 圧配置が強まった15日から16日にかけて大雪となり，長崎市では 34 年ぶりに $10 \mathrm{~cm}$ を超える積雪 $14 \mathrm{~cm}$ 記録した。なお冬季の測定期 間前後の日別天気概況を表 2 に示す ${ }^{13)}$ 。

\section{4. 測定結果}

\section{1 夏季の測定結果}

図3に, 夏季の場合のアーケード内部における地上からの各高さ の気温と外気温, 日射量, 相対湿度, ならびに風速の時間変化を, 前後 5 分間合計 10 分間の移動平均値で示す。なおこれ以後, 全てこ の移動平均値を用いて考察を行う。

図中の凡例の, 例えば「+6.5m」は「地上 $6.5 \mathrm{~m}$ (図 2 参照) で 測定された気温」の意味である。またグラフ中の「内部・日射・上 面」は, アーケード内部に設置した長短波放射計によって測定され 
表 2 測定期間前後の長崎海洋気象台における天気概況

\begin{tabular}{|c|c|c|}
\hline 月 日 & 天気卙況（6持～18時） & 天気概涗（18時 一 6 時) \\
\hline 8月18日 (金) & 大雨時々曼，雷を伴う & 墨一時雨後一時晴 \\
\hline 8月19日（土） & 晴後一時薄需 & 大雨時々重，雷を伴う \\
\hline 8月20日（日） & 雨一時雵, 雷を伴う & 雨一時量, 雷を伴う \\
\hline $8 / 21 / 16(1)$ & 藇時々雨後一時晴 & 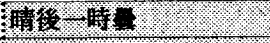 \\
\hline 8 月22月 (K) & 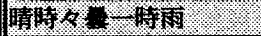 & 棈 \\
\hline $8 \cap 23 \sqcap(8)$ & 棈 & 籍 \\
\hline 8 ค24ณ (K) & 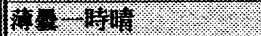 & 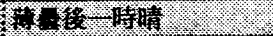 \\
\hline 89254 (사) & 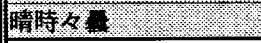 & 晴後一時雨 \\
\hline 1月13日 (土) & 雨後一時晴 & 量後時々雪 \\
\hline 1月14日 (日) & 雪 & 雪一時みぞれ \\
\hline 1月15日 (月) & 大雪 & 雪 \\
\hline 1 月16日 ( ( ) & 雪一時晴 & 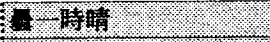 \\
\hline 1. II 17 月 $(1 \times)$ & 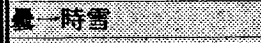 & 10 \\
\hline $1918 \mathrm{E}(1)$ & 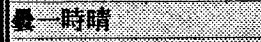 & $4 x_{1}=4$ \\
\hline $1.71919 .(1)$ & 10 & \\
\hline
\end{tabular}

た，水平面より上半球側から入射する日射量であり，「内部・日射・ 下面」は下半球側から入射する日射量である。「外部・日射」は， アーケードの外部・屋上に設置した全天日射計によって測定された 日射量である。図が小さいため細部の読み取りはできないが，時間 変化の概要を知ることができる。

日射があると，アーケード内部の気温が上昇し，上層部と下層部 の温度差も大きくなることがわかる。アーケード内部の最高気温は, 内部の気温分布のうちの道路側の最上部（地上6.5 m) で, 8 月 23 日14:51に測定された $39.9^{\circ} \mathrm{C}$ (移動平均值では, 同日14:55の37.6 ${ }^{\circ} \mathrm{C}$ ) であり，この時の外気温は $36.8^{\circ} \mathrm{C}$ (移動平均值では, $35.6^{\circ} \mathrm{C}$ ) であっ
た。また内部・地上（地上 $1 \mathrm{~m}$ ) の気温は, 最高 $36.8^{\circ} \mathrm{C}$, 最低 26.2 ${ }^{\circ} \mathrm{C}$ (移動平均值では, 最高 $35.1^{\circ} \mathrm{C}$, 最低 $26.4^{\circ} \mathrm{C}$ ), 測定期間中の外 気温は, 最高が $37.1^{\circ} \mathrm{C}$, 最低が $25.5^{\circ} \mathrm{C}$ (移動平均值では, 最高 34.4 ${ }^{\circ} \mathrm{C}$, 最低 $25.7^{\circ} \mathrm{C}$ ) であった。

\section{2 冬季の測定結果}

図 4に, 冬季の場合のアーケード内部における地上からの各高さ の気温と外気温, 日射量, 相対湿度, ならびに風速の時間変化を, 前後 5 分間合計10分間の移動平均值で示す。なお図中の凡例などは,

夏季の場合の図 3と同様である。

アーケード内部の最高気温は, 内部の気温分布のうちの店側の地 上2.5mで，1月18日14:17に測定された $14.6^{\circ} \mathrm{C}$ (移動平均値では, 道路側の最上部（地上 $6.5 \mathrm{~m}$ ）における同日 $14: 22$ の $10.4^{\circ} \mathrm{C}$ ) であり, この時の外気温は $8.2^{\circ} \mathrm{C}$ (移動平均值では， $8.0^{\circ} \mathrm{C}$ ) であった。また 内部・地上 (地上 $1 \mathrm{~m}$ ) の気温は, 最高 $9.7^{\circ} \mathrm{C}$, 最低 $0.3^{\circ} \mathrm{C}$ (移動平 均值では, 最高 $9.3^{\circ} \mathrm{C}$, 最低 $0.5^{\circ} \mathrm{C}$ ), 測定期間中の外気温は, 最高 が $9.6^{\circ} \mathrm{C}$, 最低が $-0.8^{\circ} \mathrm{C}$ (移動平均値では, 最高 $8.24^{\circ} \mathrm{C}$, 最低 -0.7 ○) であった。

日射があっても，夏季とは異なり，アーケード内部の上層部と下 首部の温度差がほとんど見られない。これは，夏季に比べて日射量 が少ないためであると考えられる。冬季は日射量そのものが少なく なっている上に, 太陽高度が低いため, 周辺の建物に遮られるなど して,アーケード内部に侵入するエネルギーが小さくなり，その結 果, アーケード内部の気温に及ぼす影響も少なくなったと考えられ る。

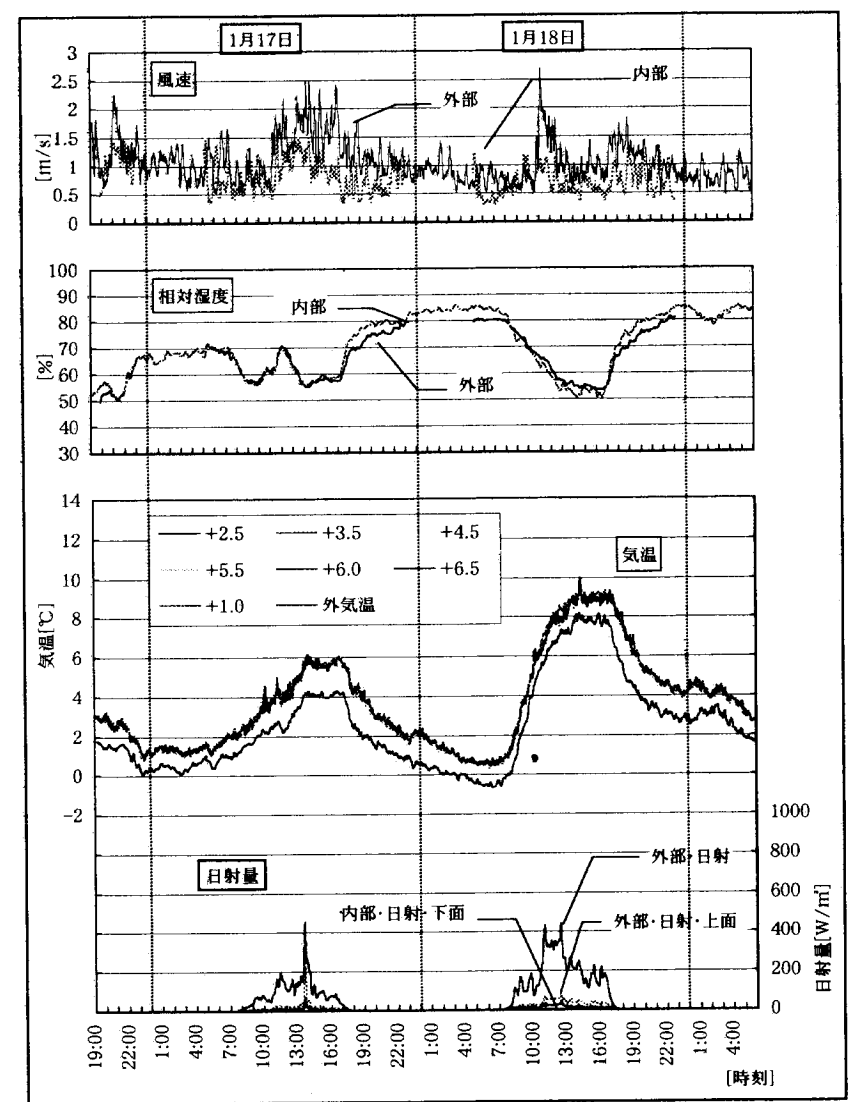

図4冬季の地上からの高さの気温と外気温，日射量，相対湿度ならびに風速

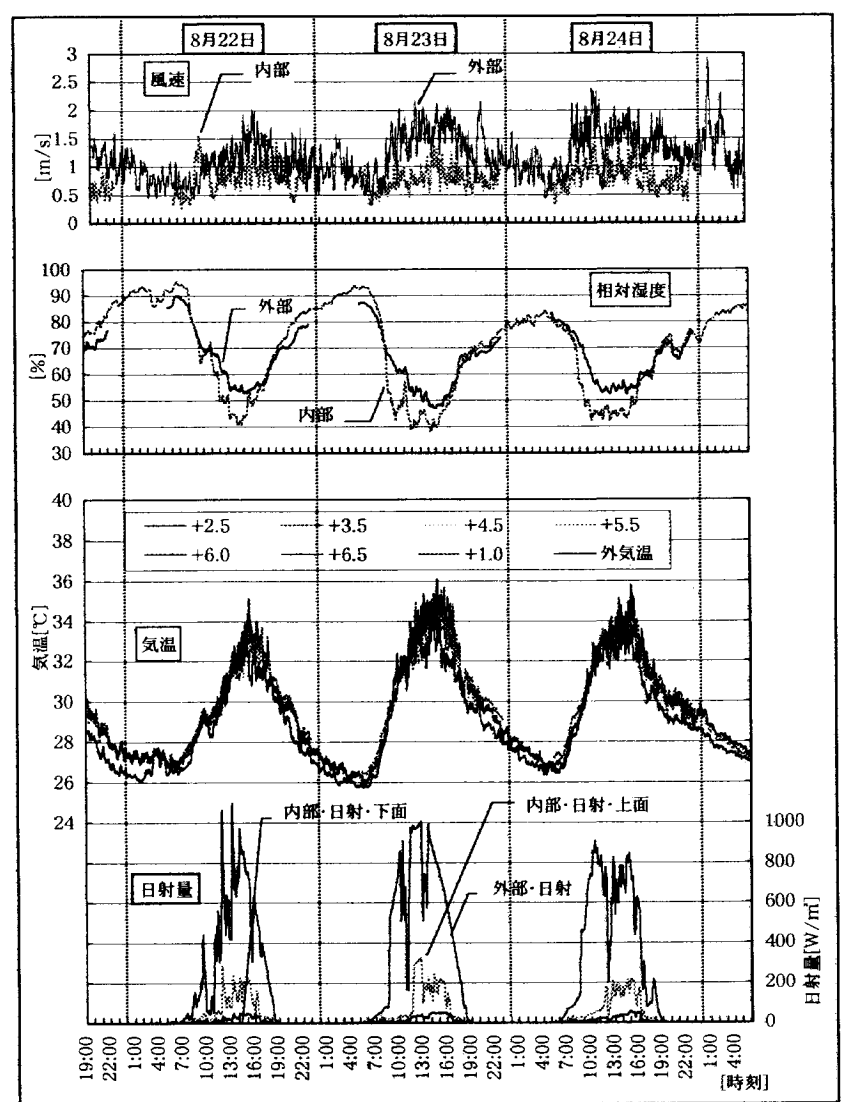

図 3 夏季の地上からの各高さの気温と外気䀅、日射量，相対湿度ならびに風速 


\section{5. アーケード内部の気温分布性状}

\section{1 夏季の気温分布性状}

夏季におけるアーケード内部の気温分布を，8月23日と 24 日の 9:00から19:00まで 2 時間おきに図 5と図 6に示す。縦軸が地上から の高さ, 横軸が温度である。縦軸上の「外気」は外部・屋上で測定 した外気温である。2 時間おきの時刻の選択は，測定を行った商店 街を人々が利用する時間帯を考虑して行った。加えて, 参考として 同じ日の正午12:00および深夜23:00の垂直分布も示す。

図 5と図6から，以下の特徵が指摘できる。

(1)一日を通して，地上 $1 \mathrm{~m}$ 気温は外気温よりも高い。

(2)日中の気温は，上方ほど高い分布を示している。

(3)夜間は，垂直方向への気温分布の勾配は解消する。

(1)については, 内部測定地点では, 店舗から吹き出す冷気の影響 が小さいため, また後述のようにアーケード内部でおこっている空 気流動の影響を受けにくいため, と考えられる。全蓋式アーケード の場合では, 両側の店舗から吹き出した冷気の影響で, 外部よりも 内部・地上 $0.5 \mathrm{~m} の$ 気温が低かった ${ }^{2)}$ が, 今回対象とした片側式ア一 ケードに接する店舗では，店舗の出入り口を常時開放していない場 合が多いため，冷気の吹き出しは少なく，逆の現象が見られた。

(2)については，地上 $1 \mathrm{~m} \sim 5.5 \mathrm{~m}$ までは大きな勾配がみられず, 地上 $5.5 \mathrm{~m} \sim 6.5 \mathrm{~m}$ の間で大きな勾配がみられることから，全蓋式アー ケードの場合と同様2)，天井から約 $1 \mathrm{~m}$ 下までの範囲に暖かい空気 が存在していたと考えられる。今回の測定結果では, 勾配は最大で 約 $3 \mathrm{~K} / 1 \mathrm{~m}$ であり, 最大で約 $11 \mathrm{~K} / 1 \mathrm{~m}$ であった ${ }^{3)}$ 全蓋式アーケー ドの場合の約 $1 / 4$ の緩やかな勾配である。

また，同じく全蓋式アーケードの場合では，アーケードの屋根の 内側表面温度が最高 $46.4^{\circ} \mathrm{C}$ で, 屋根直下の気温が最高 $41.9^{\circ} \mathrm{C}$ とその

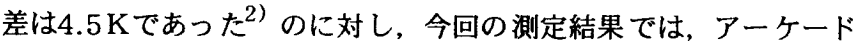
の天井の内側表面温度が最高 $49.0^{\circ} \mathrm{C}$ で, 天井直下の地上 $6.5 \mathrm{~m}$ の気 温が最高 $36.7^{\circ} \mathrm{C}$ との差は $12.3 \mathrm{~K}$ と大かった。

さらに，測定対象アーケードの天井面は開口率約 $50 \%$ のパンチン グメタルが用いられ，その上方のアーケード最上部に排煙用のガラ リが取り付けられている（図 2 参照）ことから, 全蓋式アーケード の場合とは異なり，温度差換気がなされていたものと考えられる。 すなわち, 图 2 のアーケード左側の日除けの下方の開口部（柱があ る部分以外）から空気が流入し，天井面のパンチングメタルを通過 し，アーケード最上部のガラリから空気が排出される，という温度 差換気がなされていたと考えられる。このことはさらに,アーケー

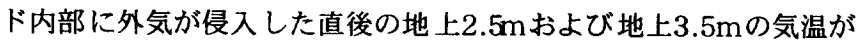
外気温とほぼ同じであることからも裏付けることができる。

これらのことから, 前述の地上 $1 \mathrm{~m}$ 気温が地上 $2.5 \mathrm{~m}$ や地上 $3.5 \mathrm{~m}$ の気温よりも高いことも説明が可能であると考えられる。す なわち、アーケードの内部・地上の開口部分とは反対側の店舖側の 地上付近は, 温度差換気の際におこっている空気流動の影晦を受け にくく，暖かい空気が滞留していたと考えられる。

なお, 道路側の地上 $6.5 \mathrm{~m}$ と柱部分の地上 $3.5 \mathrm{~m}$ の気温が他の気温 よりも高いのは, これらの気温測定点はアーケードの屋根や日除け のガラスを支えるための鋼管に近いところに位置しており，日中は そこへ日射があたって付近の気温も上昇し，それが測定值に現れた ためと考えられる。
(3については, 夕方になるとまず外気温が下がり，さらに日射が なくなった結果，アーケード上方の空気が暖められず，やがて，気 温分布に勾配がなくなったと考えられる。その結果, 温度差換気の 効果が昼間に比べて小さくなり，放射冷却の影響で昼間に比べて低 くなった外気温に比べて, 内部の気温が高い状態が続いたと考えら れる。

\section{2 冬季の気温分布性状}

冬季におけるアーケード内部の気温分布を，1月18日の9:00から 19:00まで 2 時間おきに图 7に示す。加えて, 参考として同じ日の 正午12:00および深夜23:00の垂值分布も示す。なお図中の凡例など は，夏季の場合の図 5および図 6と同様である。

図7から，以下の特徵が指摘できる。

(1)一日を通して，地上 $1 \mathrm{~m} の$ 気温は外気温よりも高い。

(2)一日を通して，アーケード内部の気温は, 上方から下方まで ほぼ同じ分布を示している。

(1)については，夏季と同様，地上 $1 \mathrm{~m} の$ 気温は外気温よりも最大 約 $2 \mathrm{~K}$ 高く，これは全蓋式アーケードの場合 ${ }^{2)}$ とほほ同じ値であっ た。これには, 赤外線表面温度計によって測定されたアーケードに 接する店舗 1 階の表面温度が地上 $1 \mathrm{~m}$ 気温より一日を通して0.7 〜 $2.9^{\circ} \mathrm{C}$ 高かったことから，建物からの熱流の影響が考えられる 注 4)

(2)については，日中の地上6.5mと19:00の地上 $2.5 \mathrm{~m}$ を除いて， アーケード内部の気温はほほ同じであった。夏季に比べて日射量が 少なく，その結果アーケード上方の空気が暖められにくいため，夏 季の場合に比べて温度差換気の効果がほとんどなかったものと考え られる。ただし日中には，アーケード上方の気温分布にわずかなが ら勾配がみられ，少ないながらも空気流動もみられたと考えられる。 このことは, 日中の地上 $1 \mathrm{~m}$ の気温が地上 $2.5 \mathrm{~m}$ の気温より若干高 かったことからも推測される。

19:00の地上 $2.5 \mathrm{~m} の$ 気温が高いのは, 店舗の看板に点灯されてい た影響であると考えられる。夏季では看板周辺の気温が冬季よりも 高いため, 冬季に比べて看板の表面温度と気温に大きな差がないが, 冬季では両者には大きな差があるため, 測定値にその効果が現れた と考えられる。

全蓋式アーケードの場合 ${ }^{2)}$ では, 冬季の夜間の気温は, 上方ほど 低い分布を示していたが，今回の測定ではこのような傾向は見られ なかった。これは, 全蓋式アーケードの上方部分は, ポリカーボネ イト樹脂板を介しただけで外気に接しているのに対し，今回対象と した片側式アーケードの場合, パンチングメタルの天井の上方に更 に消火足場が設置されており, 直接外気に触れていないため, 放射 冷却の影響をほとんど受けていないためであると考えられる。

\section{6. まとめ}

アーケード空間の熱睘境設計に資するため，長崎市に位置する新 設された片侧式アーケードを対象とし，夏季と冬季の 2 度に分けて 内部の気温分布を中心に熱環境測定を行った。得られた結果は以下 の通りである。

1) アーケード内部の地上 $1 \mathrm{~m} の$ 気温は, 全蓋式アーケードとは異 なり，夏季と冬季ともに，1 日を通して外気温より高かった。 

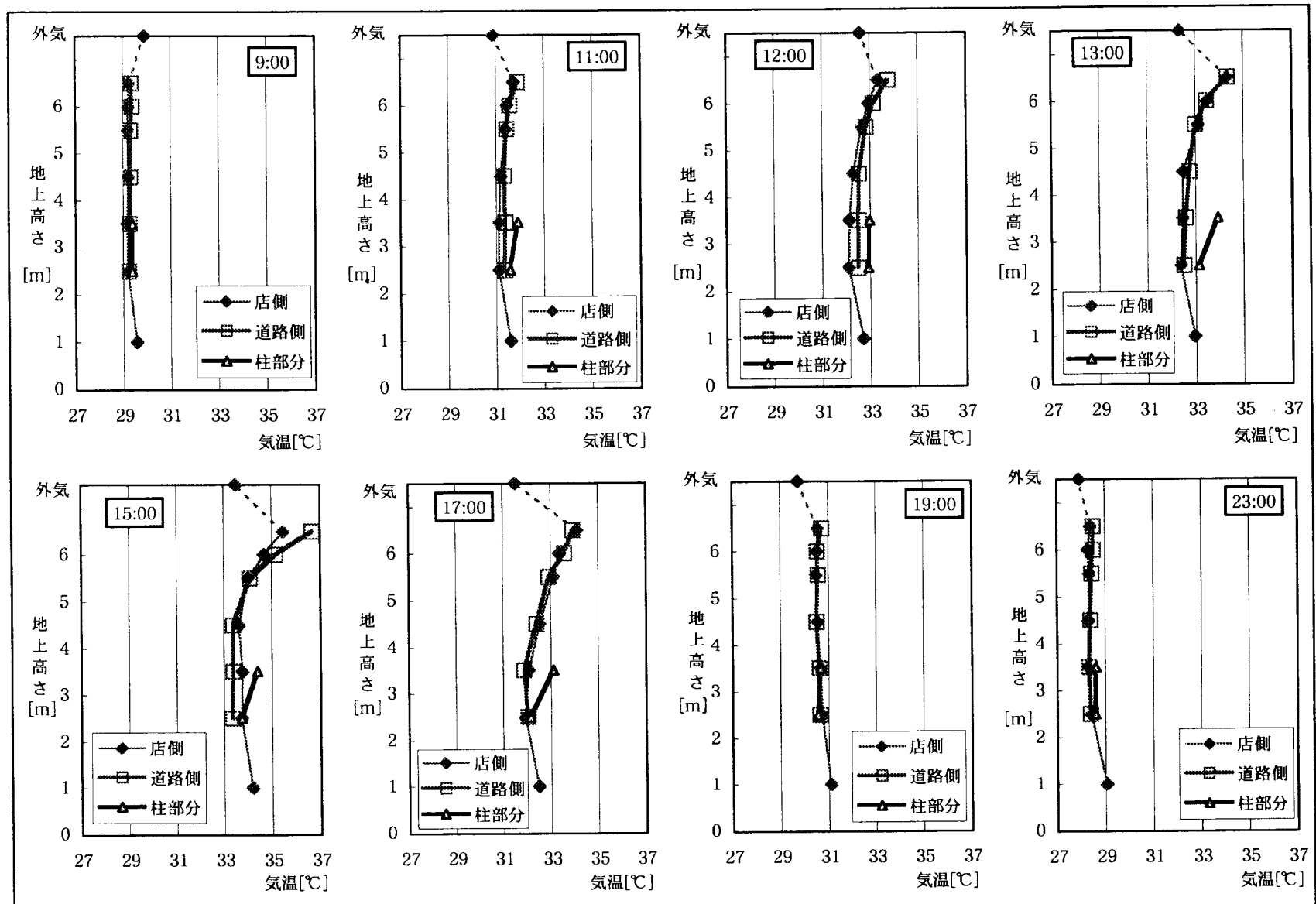

図 5 8月23日における気温の垂直分布の時間変化
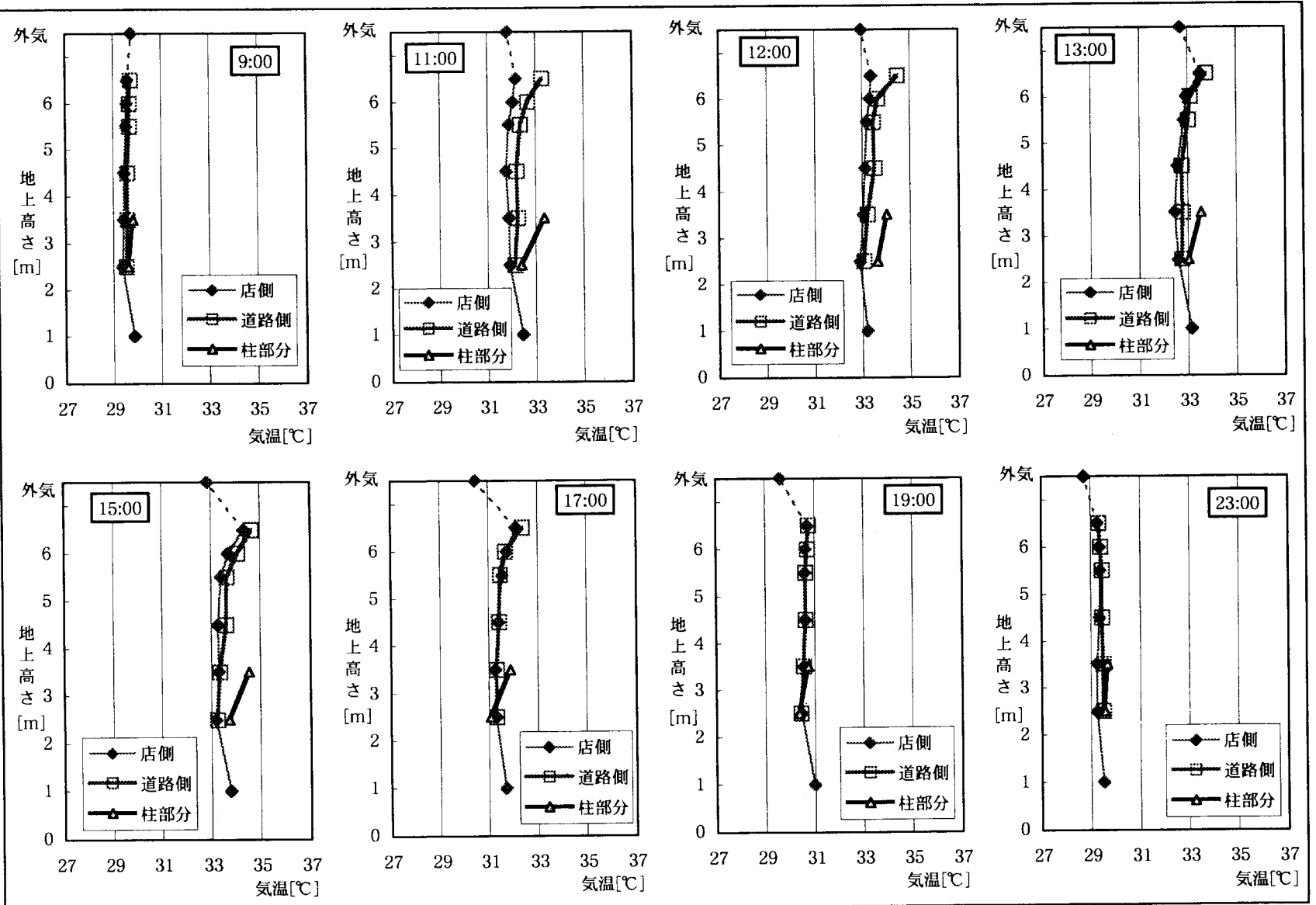

図 6 8月24日における気温の垂直分布の時間変化 

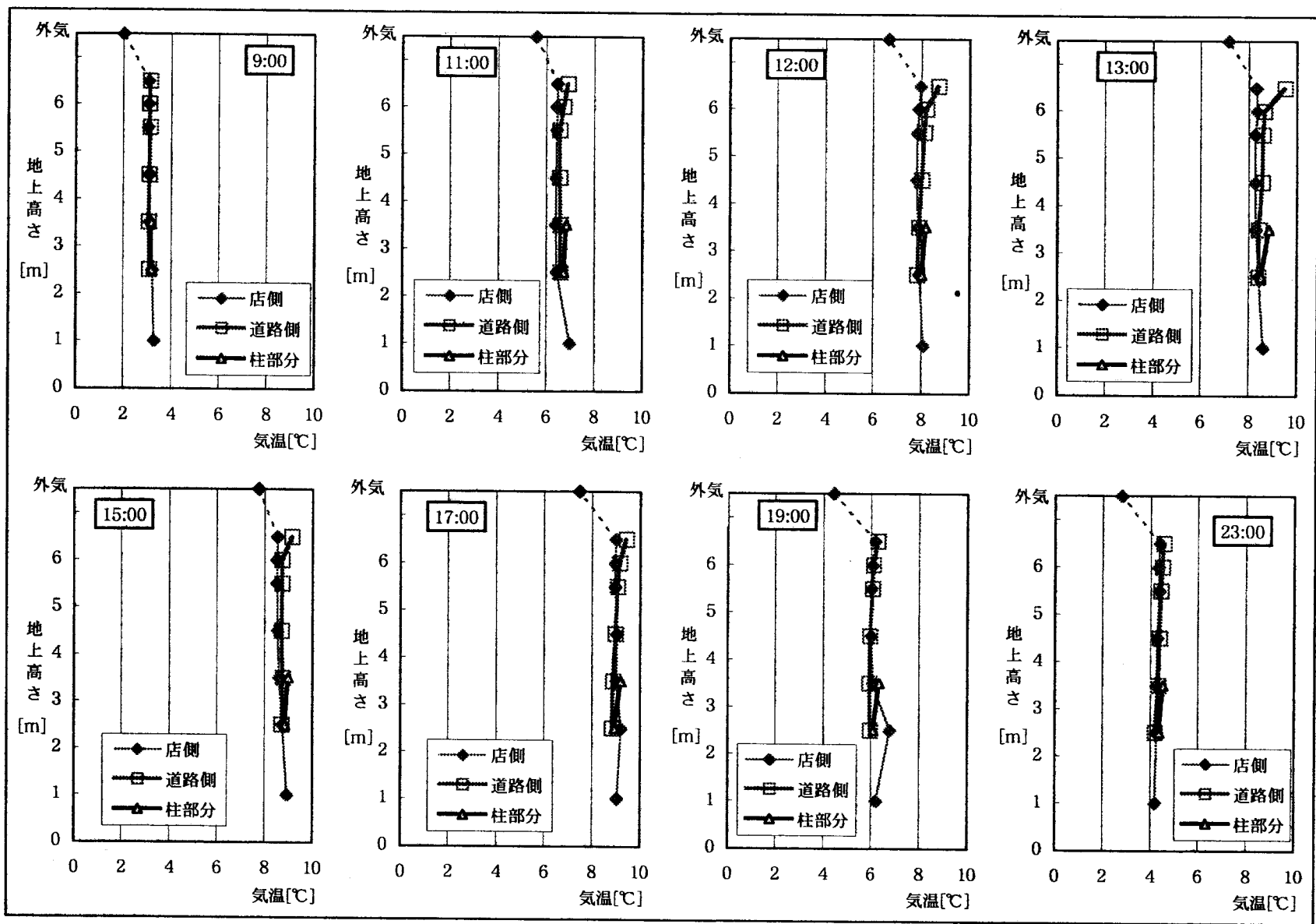

図 7 1月 18 日における気温の垂直分布の時間変化

2 ）夏季の日中の気温は, 上高下低の垂直分布を示し、アーケード 内部の上層部には暖かい空気が存在していたが, 全盖式アーケー ドと同様，その厚さは約 $1 \mathrm{~m}$ 程度以下であった。

4) 冬季の日中の気温は, 上方から下方までほぼ同じ垂直分布を示 したが，これは夏季に比べて日射量が少ないためと考えられた。

5) 夏季の日中のアーケード内部では，アーケード側方の開口部か ら空気が流入し, 最上部のカラリから排出されるという温度差 換気による空気流動が見られたと推測された。

謝辞：調查にご協力いただきました長崎浜市垂車通商店街振興組合の皆様。 また風速計をお貸しいただいた熊本大学工学部石原研究室に篤く胙礼 を申し上げます。な排定には, 当時熊本県立大学生活科学部 4 年生 の鬼木良子さん，町田友美枝さん，八橎真樹子さん，矢野詩史さんの 多大な協力がありました。

<脚注>

注 1）都市の「半戸外空間」とは，「建築内部の室内空間と.屋外空間の中間 に位闐する都市施設により形成される空閏」のことである゙)。

注 2）「道路の全面又は大部分をおおうアーケード」を「全盖式アーケー ド」，「道路の一㑡又は両側に設けるアーケード」を「片側式アーケー ド」と呼ぶ。なお文献2）および3）では，「全蓋式」を「全蓋型」と している。

注 3）文献2）では、「最大で約 $6 \mathrm{~K} / 10 \mathrm{~m}$ の勾眍である。」となっているが， 論文中のグラフからこの記述は誤りであり，「最大で約 $11 \mathrm{~K} / 1 \mathrm{~m} の$ 勾 配である。」が正しいと考えられる。

注 4) なお今回の測定では, 道路上の気温の測定を行っていないため, 道路 上の廃䓡などの影䇾については言及しないこととする。
<参考・引用文献〉

1) 辻原万規彦，小林正美，中村泰人，外山義 : 西日本における都市のア一 ケードの成立および発展過程, 日本建築学会計画系論文集, 第524号, pp.215 222, 1999.10

2）辻原万規彦，中村泰人，田中稳，大塚順基：温暖多照地域における全蓋 型アーケード内部の気温分布性状, 日本建案学会計画系論文集, 第 508 号, pp.43〜 50, 1998.6

3）辻原万規㢁, 中村泰人, 田中稳, 岡村圭子, 梅宮典子: 温暖多照地域に おける全盖型アーケード内部の温鶖環境の評価，日本建築学会計画系論 文集, 第514号, pp.43〜 50,1998.12

4）辻原万規彦，中村泰人，田中稳：都市の半戸外空間内部の温帮眭境に関 する地城の差異を考慮した倸価方法の提案, 日本建築学会計画系論文集, 第519号, pp.101 108，1999.5

5）辻原万規彦, 平川真由美, 田中稳: 片侧式アーケード内部の温整器境に 関する調査研究 その 1 夏季の実湖結果, 日本建築学会九州支部研究 報告、第40号・2 [環境系]，pp.125 128，2001.3

6）辻原万規彦, 平川真由美, 田中稳: 片則式アーケード内部の温熱琹境に 関する調查研究 その 2 冬季の実测結果, 空気調和・衛生工学会九州 支部研究報告, 第 8 号, pp.75 80,2001.5

7) 田栗重昨著, 石丸太郎編钲: 長崎浜の町繁昌記, p . 344, 浜市商店連合 会, 1983.1

8）永田信孝：新・ながさき風土記 地図と数字で見る長崎いまむかし， p.14, 長崎出岛文庫, 1999.11

9）中村泰人，平岡久司，西村浩一: 市街地空間における気温分布性状に関す る実駼的研究，日本建築学会計画系詥文報告集, 第364号, pp.49 50. 1986.6

10）長崎海洋気象台: 長崎県気象月報 平成12年（2000年） 8 月, 長崎海洋 気象台, 2000.8

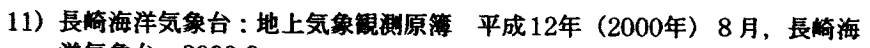
洋気象台, 2000.8

12）長崎海洋気象台：長崎県気象月報 平成13年（2001年）1月，長崎海洋 気象台, 2000.1

13）長崎海洋気象台: 地上気像観測原簿 平成 13年（2001年）1月, 長崎海 洋気像台, 2000.1

[2001年 4 月19日原稿受理 2001年 7月27日採用決定］ 